\title{
Islamic Sharia in the Legal Orders of Saudi Arabia and Kuwait
}

\author{
Salma Wabeedi
}

\begin{abstract}
This chapter provides a background and overview of the place and role of Islamic law in the constitutional orders of Saudi Arabia and Kuwait. It discusses the place of Islamic sharia in the constitutional structure, court system, legal framework, and approaches to religious freedom protections in these facially similar but also significantly diverging political systems. It demonstrates, contrary to prevalent western assumptions, that the inclusion of a commitment to Islam in a given constitutional order does not simply lead to any pre-determined uniform outcomes, nor does it exclude secular law from the legal order. Even in Saudi Arabia, where the Basic Law commits to full Islamization of the legal system, practical and contemporary needs have led to the adoption of an increasingly hybrid legal system in response. The interpretation and application of sharia in law and practice continues to evolve and shift with changing political dynamics and public policy considerations.
\end{abstract}

\section{Introduction}

Most majority Muslim countries have adopted constitutions that entrench a national commitment to Islam and a role for Islamic sharia in shaping their legal systems. ${ }^{1}$ The most commonly adopted constitutional commitment to Islam by far is the Islamic establishment clause, which generally provides that Islam is the religion of the state. A more concrete clause is termed the Islamic source of law clause, which provides that Islamic sharia, or principles of sharia, are "a" source or "the" primary source of legislation,

1 For a background, history, and analysis of these clauses across different Arab constitutions, see Clark Lombardi, "Constitutional Provisions Making Sharia 'A' or 'The' Chief Source of Legislation: Where Did They Come from? What Do They Mean? Do They Matter?” American University International Law Review 28.3, January 2013: 737-774. See also, Dawood I. Ahmed and Moamen Gouda, "Measuring Constitutional Islamization: the Islamic Constitutions Index." Hastings International and Comparative Law Review 38.1, 2015: 1-76. 
thus committing to a more concrete role for Islam in national lawmaking. Even stronger language sometimes appears in the form of a repugnancy clause, which declares any law in contradiction to Islamic sharia to be invalid.

The inclusion of any of these clauses in a national constitution, particularly the Islamic source of law and repugnancy clauses, immediately gives rise to a number of substantive and structural questions. The Arabic term "sharia" means "path," and it is broadly used to refer to the divine, immortal, and unchanging law of God. The specific meaning of sharia and the particular rules it encompasses are, in turn, elaborated through fiqh (jurisprudence), which is a human exercise of deriving rules from the interpretation of the Quran and sunna (Prophet's traditions). ${ }^{2}$ There is hardly any agreement among Muslims, with respect to the meaning and interpretation of sharia, and there is no uniform set of fiqh outcomes to apply. This dilemma with respect to substance is compounded by the lack of a uniform Islamic "institutional design" to guide the establishment of structures that may interpret Islamic constitutional clauses and ensure the compatibility of national legislation with sharia. ${ }^{3}$

Commitments to constitutional Islam, in all their subtle variances, are often outcomes of complex internal political dynamics and the significance of their impact in shaping legal systems and institutional judicial structure is also highly context-dependent. Arab Gulf monarchies are prime examples of conservative predominantly Muslim states, with strong commitments to sharia in their constitutions. This article focuses on Saudi Arabia and Kuwait in particular, both ruled by tribal monarchies but nonetheless diverge significantly in their political structures, levels of popular participation in lawmaking, and most importantly for the purposes of this article, the position of Islamic sharia in their constitutional order.

Since the establishment of the Saudi state, it has declared a commitment to create a legal system that is most representative of an Islamic governance model. Its Basic Law, promulgated in 1992, states emphatically that it is not a constitution but rather that the Quran and sunna of the Prophet are

2 For a primer on Islamic law and its sources, see Wael Hallaq, The Origins and Evolution of Islamic Law. Cambridge: Cambridge University Press, 2004.

3 For a discussion of the different models of judicial review in countries with sharia provisions in their constitutions, see Salma Waheedi and Kristen Stilt, "Judicial Review in the Context of Constitutional Islam.” Comparative Judicial Review, edited by Erin F. Delaney and Rosalind Dixon. Cheltenham, UK and Northampton, MA, USA, 2018: 117-141. 
"the constitution," ${ }^{4}$ and outlines provisions throughout its text that emphasize the integral role of sharia in legislation and adjudication, while offering only limited rights protections. Kuwait, on the other hand, adopted a constitution following its independence from Great Britain that reveals an aspiration to create a more inclusive legal system that, notwithstanding strong commitments to Islam, emphasizes equality, non-discrimination, and protection of citizens' rights. The main commitment to sharia in the 1962 Kuwaiti Constitution is expressed in Article 2, which declares Islam as the state religion and sharia as "a primary source of legislation." ${ }^{5}$ In turn, the application and interpretation of this article is delegated to the judiciary. These different approaches to the positioning of Islamic sharia in the two constitutional frameworks then translate into structurally and substantively diverging legal systems and judicial institutional structures, with each corresponding to different historical and political trajectories.

This article provides an overview of the role of Islamic law in the constitutional order of Saudi Arabia and Kuwait, covering their constitutional frameworks, legal systems, judicial structures, and approaches to freedom of religion. It also demonstrates, contrary to prevalent western assumptions, that the inclusion of a commitment to Islam in a given constitutional order does not simply lead to any pre-determined uniform outcomes, nor does it exclude secular law from the legal order. Even in Saudi Arabia, where the Basic Law commits to full Islamization of the legal system, practical and contemporary needs have led to the adoption of an increasingly hybrid legal system in response. Hybridity, in fact, is a visible characteristic in the legal systems of all Arab countries without exception, as sharia based laws continue to coexist with secular laws, and the interpretation and application of sharia related constitutional clauses have, time and again, proven to be fluid and evolving in line with shifting political dynamics and public policy considerations.

\section{Saudi Arabia}

\subsection{Sharia in the constitutional and legal framework}

Saudi Arabia's legal system and its commitment to Islam can only be understood in the context of the history of emergence of the modern Saudi

4 Basic Law of Saudi Arabia (1992), art. 1.

5 Constitution of Kuwait (1962), art. 2. 
state and the founding pact between the Al Saud ruling dynasty with the puritan Salafi movement of Muhammad bin Abd al-Wahhab (d. 1792), whereby Saudi rulers ceded broad control of all matters related to religion, its interpretation, and application, in exchange for political power and legitimacy. ${ }^{6}$ This alliance between the ruling family and powerful Salafi religious forces has endured since the establishment of the Saudi state, and it was only in recent decades that monarchs began to gradually chip away at the tight grip of religious scholars on the legal system through a process of institutionalization and bureaucratization of state apparatus. One of the most significant reforms in this respect was King Faisal bin Abd al-Aziz Al Saud's issuance of a 1971 Royal Order institutionalizing the Council of Senior Scholars (Hay'at Kibar al-Ulama) as a state body whose members are appointed directly by the King and paid by the state. The Council, presided over by the Grand Mufti, is the Kingdom's most senior religious authority and is responsible for advising the King and government on all religious matters. It is also responsible for issuing official fiqh opinions, or fatwas, which have strong public and political influence, even as they are not legally binding in a formal sense. ${ }^{7}$

The Basic Law of Saudi Arabia was promulgated seventeen years later by King Fahad in 1992, with the broad support of the Council of Senior Scholars. ${ }^{8}$ The Basic Law of 1992 is often referred to as Saudi Arabia's Constitution, and it generally functions as one - yet the document itself states that "the constitution of the state" shall be the Quran and the sunna (traditions) of his Prophet.9 Article 1 of the Basic Law establishes that Saudi Arabia is an Arab Islamic state and declares Islam to be the state religion. Article 1 is then followed by provisions that entrench Islamic sharia as the foundation of all legislation, governance, and adjudication. Article 7 establishes the Quran and sunna as the [sole] sources of authority and legitimacy of the regime, and declares them supreme over all other

6 For a historic overview of the role of sharia in the law and politics of Saudi Arabia, see Frank E. Vogel, "Saudi Arabia: Public, Civil, and Individual Shari'a in Law and Politics.” Shari'a Politics, edited by Robert H. Hefner. Indiana: Indiana University Press, 2011: 55-93.

7 Royal Order of King Faisal bin Abd al-Aziz Al Saud (3 September 1971). See the Council's website for current members, fatwas, and other related information and services, https://www.alifta.gov.sa/Ar/Pages/default.aspx.

8 For a historical contextualization and discussion of the Basic Law's drafting and promulgation process, see Abdulaziz H. Al-Fahad, "Ornamental Constitutionalism: The Saudi Basic Law of Governance.” Yale Journal of International Law 30, 2005: 376-96.

9 Basic Law of Saudi Arabia (1992), art. 1. 
laws, including the Basic Law itself. Article 8 emphasizes that the system of governance is based on justice, shura (consultation), and equality, "in accordance with the Islamic sharia." Article 23 of the Basic Law then compels the state to "protect the Islamic creed and apply Islamic sharia." The rights and duties of citizens and the powers and authorities of the monarch and state institutions are all formulated with explicit recurrent references to their Islamic basis. ${ }^{10}$ The Basic Law includes provisions throughout its text that enshrine the foundational role of sharia in guiding legislation, governance, and adjudication.

In practice, lawmaking in Saudi Arabia belongs to one of two domains, a fiqh domain - where sharia-based law is judge-made and applied in accordance with judges' interpretation of sharia - and a siyasa (policy) domain, where the King issues codified laws, often called regulations (sing. nizam) to distinguish them from sharia law; the scope of what the siyasa domain comprises is determined by the King in accordance with public interest. ${ }^{11}$ Primary examples of codified siyasa laws and regulations include primarily business, banking, and insurance-related regulations, such as the Banking Control Regulations of 1966, the Labor Regulations of 1969 (amended and reissued in 2005), the Social Insurance Law of 2000, the Cooperative Insurance Companies Control Law of 2003, and the Companies Law of 2015 , in addition to procedural regulations governing the functions of state institutions and the court system.

The majority of laws in Saudi Arabia, however, remain uncodified and subject to figh interpretations. For example, to date there is no written criminal law, family law, or contracts law in Saudi Arabia, and this lack of codified legislation continues to be a fundamental source of uncertainty and lack of consistency in the application of justice, as judges continue to enjoy wide discretion in applying their own personal preferences and fiqh interpretations. In 2010, the government announced its intention to "codify the largely unwritten sharia regulations governing the kingdom's criminal, civil and family courts in order to bring more clarity and uniformity to judicial rulings," 12 but instead of issuing legislation, this codification took the form of publishing annual compendiums of judicial rulings as pdf documents, which are available on the website of the Ministry of

10 Basic Law of Saudi Arabia (1992), Part 5: Rights and Duties; Part 6: Authorities of the State.

11 See Frank E. Vogel, "Shari'a in the Politics of Saudi Arabia." Review of Faith and International Affairs 10, 2012: 18-27.

12 Caryle Murphy, "Saudi to Codify Sharia for Clarity." The National, 21 July 2010, https://www.thenational.ae/world/mena/saudi-to-codify-sharia-for-clarity-1.518063 
Justice. ${ }^{13}$ While these provide some clarity on the treatment of certain issues by courts, the lack of a system of binding precedent, and the grant of wide discretion to judges to apply unwritten sharia law as they interpret it individually, renders these published rulings of limited practical value.

Saudi Arabia's Basic Law also empowers judges to refrain from applying any law they deem contrary to the Islamic sharia. Article 46 states that "the judiciary is an independent authority, and judges are not subject to any authority except to that of the Islamic sharia." Article 48 adds that "courts shall apply the tenets of the Islamic sharia, as directed by the Quran and sunna," as well as apply laws decreed by the ruler that "do not contradict the Quran and sunna." The Basic Law therefore practically places manmade law under the scrutiny of judges. In theory, at least, a Saudi judge may refrain from applying a nizam if he deems it incompatible with the Quran and sunna (as interpreted by that particular judge), although, depending on the political circumstances and degree of sensitivity of the case in question, it may not always be politically feasible to do so. In any case, refraining from applying such a regulation does not mean that the regulation is no longer generally applicable; rather, the judge's choice would only apply to the particular dispute before him. The ability of judges to refuse to apply codified regulations may also be circumvented by including provisions in the law which establish specialized tribunals within the executive branch with jurisdiction to apply them, thus bypassing the regular courts. ${ }^{14}$

\subsection{Islamic sharia and the judiciary}

The original institutional design of the judiciary in Saudi Arabia granted the religious establishment, represented by the jurist-judges, broad powers to apply and monitor the compliance with what they determine to be sharia law. The grant of these powers to the judiciary was an established de facto practice since the establishment of the modern Saudi state in 1932 and sharia courts of general jurisdiction have long retained broad jurisdictional powers to rule over most civil, criminal, and personal status disputes. Commercial cases have, at different points in time, been treated as an exception due to their specialized nature and economic importance

13 See "Collection of Judicial Rulings on the website of the Saudi Ministry of Justice." https://www.moj.gov.sa/ar/SystemsAndRegulations/Pages/default.aspx.

14 Vogel (2012), supra note 11 at 19. 
and were carved out of the jurisdiction of sharia courts. Specialized commercial courts were first established in $1931,{ }^{15}$ but were disbanded in 1955 and their jurisdiction was transferred to sharia courts briefly until $1960 .{ }^{16}$ In 1960, the Saudi Council of Ministers created a Committee of Commercial Disputes Settlement to assume the jurisdiction of the former commercial courts and placed this Committee under the authority of the Ministry of Commerce and Investment. ${ }^{17}$

In 1975, King Faisal issued a unified Judiciary Act as part of his wideranging administrative reforms, with a view to formally institutionalize and organize the court structure, and for the first time, established procedures to govern judicial functions. The 1975 Act divided the sharia courts of general jurisdiction into first instance courts, a Cassation Court, and a Supreme Judicial Council to serve as the highest authority of appeal. ${ }^{18}$ The Kingdom's Board of Grievances, which dates to the early founding of the state, was formalized earlier in 1954 as a state judicial institution under the supervision of the Council of Ministers, and in 1982 it was placed under the direct authority of the King. ${ }^{19}$ In 1987, the jurisdiction over commercial disputes was transferred to the Board of Grievances (Diwan al-Mazalim), ${ }^{20}$ and commercial court circuits were established within the Board to rule over both the commercial cases that fall under sharia law as well as the cases arising a codified law (formerly covered by the 1931 Commercial Courts Law). ${ }^{21}$ In addition to commercial disputes, the Board's scope of jurisdiction covered administrative cases, cases against state institutions, criminal cases arising from infractions of siyasa-based regulations, and enforcement of foreign court judgments. ${ }^{22}$ Nonetheless, up until recently, the religious establishment continued to exercise significant control of the judiciary and sharia-trained judges retained broad powers to adjudicate as they see fit, interpreting the law in accordance with their figh training and relying on any majority or minority view in the Hanbali school. Judges

15 Saudi Arabia Commercial Courts Law of 1931.

16 Saudi Arabia Council of Ministers' Decision 228 of 1960.

17 Council of Ministers' Decision 228 of 1960. In 1962, the Minister of Commerce and Industry issued Decision 277 of 1962 organizing the Committee and its appellate chamber.

18 Saudi Arabia Judiciary Act of 1975, art. 5. This was changed later by the 2007 Amended Judiciary Act.

19 Royal Order M/51 of 1982.

20 Saudi Arabia Council of Ministries Decision 241 of 1987.

21 Diwan al-Mazalim's official website, https://www.bog.gov.sa/AboutUs/Pages/Enge nder.aspx.

22 Ibid. 
were under no obligation to consider or follow neither precedent nor any specific legal rationale or basis for interpretation. Rulings often varied significantly even in identical disputes.

In 2007, King Abdullah bin Abd al-Aziz enacted a decree that introduced a wide range of reforms to the judiciary, which served to weaken the jurists' near-exclusive control of the judiciary and introduced subject matter specialization and training for judges for the first time in Saudi Arabia. ${ }^{23}$ The 2007 decree overhauled the judicial system of Saudi Arabia, creating new specialized courts of first instance, specialized courts of appeals, and a Supreme Court at the apex of the court system. Article 9 of the amended Judiciary Act of 2007 organizes the judiciary into five categories: courts of legal rights, criminal courts, family status, commercial courts, and labor courts, with the Board of Grievances transformed to serve as an administrative court. ${ }^{24}$

One of the most significant changes introduced by King Abdullah was mandating specialized professional training for judges in their respective fields of jurisdiction. It abolished the requirement that all judges must be graduates of the sharia faculty, and in Article 31(d), it allowed the appointment of graduates of law faculties - rather than only sharia graduates - to the judiciary, provided they pass an entry exam designed by the Supreme Judicial Council. In September 2012, the head of the Supreme Judicial Council issued a directive specifying a new system for appointing judges, which appears to be aimed at streamlining the appointment process and adding more systematic selection criteria. ${ }^{25}$ The new system opened judicial positions to holders of graduate degrees from the High Judicial Institute and required graduates of the sharia faculty to obtain satisfactory grades in fiqh. The new system also incorporates a personal interview by a panel of three sitting judges before an appointment is made to the judiciary. ${ }^{26}$

The Act creates the Saudi Supreme Court to serve as the highest court of appeal, removing this function from the Supreme Judicial Council. ${ }^{27}$

23 For a detailed overview of the court system and all major enacted reforms up to 2015, see Abdullah F. Ansary, UPDATE: A Brief Overview of the Saudi Arabian Legal System. NYU Hauser Global Law School Program, 2015 https://www.nyula wglobal.org/globalex/Saudi_Arabia1.html.

24 Saudi Arabia's Judiciary Law (2007), arts. 9, 17.

25 "Six Rules for Appointing New Judges to Courts" (Arabic), Okaz Newspaper, September 15, 2012, http://www.okaz.com.sa/article/506830.

26 Ibid.

27 Saudi Arabia's Judiciary Law (2007), art. 11. 
Cases may be appealed to the Supreme Court if a question arises with respect to the compliance of any particular law with sharia or if there is a dispute in jurisdiction or adjudication procedures. The Supreme Court also has mandatory jurisdiction to review hudood rulings, for example, crimes that carry a sentence of execution or stoning. ${ }^{28}$ The Supreme Court may only rule on questions of law but not questions of fact. ${ }^{29}$ In part, the Supreme Court serves as Saudi Arabia's version of an "Islamic" constitutional court, with Islamic sharia serving as its highest law against which to conduct review. ${ }^{30}$ The 2007 Judiciary Act provides that the Supreme Court is composed of a "number of judges," to be nominated by the Supreme Judicial Council and appointed by the King, and that the King selects and appointed the President of the Court. ${ }^{31}$

With the establishment of the Supreme Court, the role of the Supreme Judicial Council was reshaped and refocused to become one of regulation and oversight. ${ }^{32}$ The Supreme Judicial Council continues to be appointed by the King, but instead of consisting entirely of judges (who were senior religious scholars), the new Council would include the President of the Supreme Court, four senior judges, the Undersecretary of the Ministry of Justice, the Public Prosecutor, and three additional members to be chosen by discretion of the King. ${ }^{33}$ The Act empowers the Supreme Judicial Council to manage the employment affairs of judges, supervise the operations of courts and judges, name the presidents of first instance and appeals courts, issue guidelines for the appointment of judges, and issue court administrative regulations and establish additional specialized courts as needed in accordance with the new court structure. ${ }^{34}$

Saudi judicial reforms continue to accelerate under the rule of the King Salman bin Abd al-Aziz and with the emergence of Crown Mohammed bin Salman as the driving force behind the Kingdom's ambitious and wide-reaching program of institutional and legal reform. In 2017, the formal establishment of the new specialized commercial courts, including

28 Ibid.

29 Ibid.

30 See Waheedi and Stilt (2018), supra note 3 at 125-127.

31 Saudi Arabia's Judiciary Law (2007), art. 10.

32 See Saudi Supreme Judicial Council Official Website, https://www.my.gov.sa.

33 Saudi Arabia's Judiciary Law (2007), art. 5.

34 Saudi Arabia's Judiciary Law (2007), art. 6. 
commercial courts of appeals, was announced, ${ }^{35}$ and these courts began hearing cases in $2018 .{ }^{36}$ Labor courts were established the same year, with jurisdiction over disputes related to employment contracts, wages, employment rights, injuries, and social insurance claims, among others. ${ }^{37}$ Most recently in April 2020, Saudi Arabia announced the enactment of a new Commercial Courts Law, which clarifies the jurisdiction of commercial courts and outlines their governing rules and procedures. ${ }^{38}$ All these rapid changes, stemming from the 2007 Judiciary Act, respond to a pressing need for uniformity, predictability, and efficiency in the court system, and have also recently been complemented by various measures for automation and digitization of judicial procedures.

There are no female judges in Saudi Arabia to date. ${ }^{39}$ Historically, the exclusion of women from the judiciary was an outcome of the ight grip of the religious establishment over the justice sector. The appointment of women to the judiciary remains a controversial issue in Islamic law, and the Hanbali school - particularly in its most puritan Salafi version - takes a strict position against the appointment of women as judges. And despite the lack of a universal consensus on the matter, there is a prevalent impression amongst a significant number of Muslims that appointing female judges is inconsistent with sharia..$^{40}$ Nonetheless, women in many Muslim

35 "Saudi Arabia Sets Up Commercial Courts to Expedite Investment." Reuters, October 16, 2017, https://www.reuters.com/article/us-saudi-court/saudi-arabia-sets -up-commercial-courts-to-expedite-investment-idUSKBN1CL2DT.

36 "'There Has Never Been a Better Time to Invest in Saudi Arabia,' Says Ministry of Justice.” PR Newswire, August 8, 2019, https://www.prnewswire.com/news-release s/-there-has-never-been-a-better-time-to-invest-in-saudi-arabia-says-ministry-of-justi ce-842216592.html.

37 Ibid.

38 In June 2020, the Minister of Justice issued the implementing regulations of the Commercial Courts Law of 2020, Saudi News Agency (22 June 2020), https://www.sp a.gov.sa/viewfullstory.php?lang=ar\&newsid=2100925.

39 There has been one report of a woman appointed as an arbitrator in a commercial case, although not confirmed by any official source; see Robert Anderson, "Saudi Appointed First Female Commercial Judge,” Gulf Business (August 2, 2016), https://gulfbusiness.com/saudi-appoints-first-female-commercial-judge/.

40 There is no explicit prohibition in the Quran or sunna of women taking judicial positions, but there is also no explicit endorsement of the appointment of women to the judiciary. The Hanbali school of figh takes the position that women are not permitted to serve as judges, so does the majority of scholars in the Shafi' $i$ and Maliki Schools. The Hanafi school permits the appointment of female judges but only in civil cases. More progressive interpretations exist, citing the lack of a prohibition and the view of a number of respected jurists, such as Ibn Jarir al-Tabari, al-Hasan al-Basri, Ibn al-Qasim al-Maliki, and Ibn Hazm. 
majority countries have reached the highest positions in the judiciary, including in Tunisia, Algeria, Morocco, Egypt, Bahrain, Turkey, Malaysia, Pakistan, and Indonesia. ${ }^{41}$ In 2009, Palestine became the first in the Arab world to appoint female sharia judges. ${ }^{42}$

In 2006, women were permitted to enroll in law schools in Saudi Arabia, in a groundbreaking move at the time by King Abdullah. In 2018, the Ministry of Justice issued licenses for the first time to female lawyers allowing them to conduct some notary services, in addition to being able to secure positions in law firms and government offices. ${ }^{43}$ The number of registered female lawyers reached 487 by November $2019 .{ }^{44}$ Most recently, the Saudi Ministry of Justice implemented a number of initiatives that sought to increase the number of female employees at the justice sector, including establishing special sections for women in courts and appointing women in different supporting functions in courts. ${ }^{45}$ The Minister of Justice appointed a woman as deputy director general for alimony affairs, the most senior position held by a woman in the Ministry. ${ }^{46}$

While nothing in the laws of Saudi Arabia explicitly prevent the appointment of women to the judiciary, it is likely that the first appointment will only come as a result of a political decision by the country's highest leadership. In July 2020, the Shura Council rejected a proposal by Council member Isa al-Shahrani to permit women to serve as judges. ${ }^{47}$ This was the second attempt by a Shura Council member to advocate for the inclusion of women in the judiciary, following a 2018 rejection of a similar proposal by Shura members Latifa al-Shaalan, Faisal al-Fadhel,

41 See, e.g., "Women, Law, and Judicial Decision-Making in the Middle East and North Africa: Towards Gender Justice.” UNESCO Seminar Report, Amman, June 14, 2006, http://www.unesco.org/new/fileadmin/MULTIMEDIA/HQ/SHS/pdf/ge nder_justice.pdf.

42 See "Women in the Judiciary in the State of Palestine." UN ESCWA, E/ESCWA/ECW/2018/TP.1 (2019), https:/www.unescwa.org/publications/women -judiciary-state-palestine.

43 The notary services allow the issuance and dissolution of agencies and the documentation of all kinds of contracts; Mariam Al-Jaber, "Saudi Arabia's First Female Lawyer and Notary: This is How Society Accepted Me.” Al-Arabiya, July 15, 2018, https:/english.alarabiya.net/en/features/2018/07/15/Saudi-Arabia-s-first-female-law yer-and-notary-Here-s-how-society-accepted-me-.html.

44 January 29, 2020, https:/www.arabnews.com/node/1619676/saudi-arabia.

45 Ibid.

46 Ibid.

47 Muhammad Abu Rizq, "Saudi Women Reaching the Judiciary: Efforts Blocked by the Shura Council,” (Arabic) Al-Khaleej Online, 2 July 2, 2020, https://alkhaleej

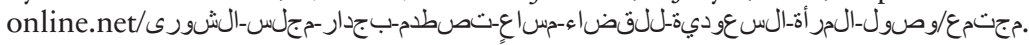


and Atta al-Subaiti. ${ }^{48}$ Notably, the Islamic and Judicial Committee of the Shura Council refused to discuss the merits of the proposal, stating that it is a matter of "internal judicial affairs" in which the Council may not interfere. ${ }^{49}$

\subsection{Religious freedoms}

Unlike the constitutions of the majority of Arab and Muslim states, the Saudi Basic Law contains very limited protections of individual rights and liberties. It guarantees certain rights, such as the right of movement, the right to privacy in one's home and secrecy of correspondence, the right to own property, and the right to education and employment. ${ }^{50}$ However, it does not include any mention of freedom of religion, expression, assembly, or demonstration, nor does it explicitly prohibit discrimination on any grounds. Human rights, according to Article 26 of the Basic Law, are protected to the extent provided in Islamic sharia. ${ }^{51}$ There is no official recognition in the Basic Law or codified laws of any religion other than Islam, or of the right of the followers of any other religion to observe or practice their religious rituals.

In practice, according to the US Department of State's Religious Freedom Report of 2019, public observance of any non-Muslim religious rituals is prohibited in Saudi Arabia, including public display of non-Islamic religious symbols, proselytizing by a non-Muslim, promotion of atheistic ideologies, or "any attempt at casting doubts about the fundamentals of Islam," and several instances of direct targeting of religious minorities have been recorded.52 Saudi Arabia has been designated as a "Country of Particular Concern” under the 1998 US International Religious Freedom

48 Ramadan Al-Sherbini, "Saudi Arabia in Renewed Bid to Empower Women in the Judiciary," Gulf News, June 16, 2020, https:/gulfnews.com/world/gulf/saudi/saudi -arabia-in-renewed-bid-to-empower-women-in-judiciary-1.1592292753024.

49 Suan Al-Yaala, "For These Reasons, the Shura Council Refused to Appoint Women Judges," (Arabic) Independent Arabic, June 19, 2020, https://www.independenta

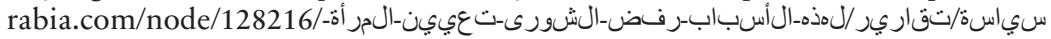
قاضية-في-السعودية.

50 Basic Law of Saudi Arabia (1992), arts. 23-43.

51 Basic Law of Saudi Arabia (1992), art. 26.

52 Saudi Arabia International Religious Freedom Report, US Department of State (2019), available at https:/www.state.gov/reports/2019-report-on-international-reli gious-freedom/saudi-arabia/. 
Act since 2004 "for having engaged in or tolerated particularly severe violations of religious freedom." 53

\section{Kuwait}

\subsection{Sharia in the constitutional and legal framework}

Kuwaiti society is deeply religious and conservative, and Islam is entrenched both in its Constitution and in the customs and tradition of the predominantly Muslim Kuwaiti population. Nevertheless, with the modern organization of the post-independence state, Kuwait adopted a legal system that was most influenced by the French civil law tradition, as adapted by Egyptian legal experts. The Constitution of Kuwait, adopted in 1962, became the first post-independence constitution in an Arab Gulf monarchy and its promulgation came about as a result of a participatory process that took place within the framework of a partially elected Constituent Assembly. ${ }^{54}$ An initial document that was drafted by Egyptian legal expert Uthman Khalil Uthman became the basis of a complex set of negotiations between popularly elected members of the Assembly, government-appointed members, and the Emir. ${ }^{55}$ Records of the discussion of the Constituent Assembly reveal careful and conscious efforts by the drafters to balance Kuwait's deeply traditional Muslim values with the desire both of the rulers and of the dominant national civil society forces at the time - to create a "modern" constitutional system that would not devolve into theocracy. ${ }^{56}$

Article 2 of the 1962 Constitution of Kuwait establishes Islam as the religion of the state and provides that Islamic sharia is a main source of legislation. While the first part of the Article may be considered a symbolic declaration of principles, the second, source of law clause, raises significant questions with respect to the role of sharia in the legislative process and

53 Ibid.

54 For an overview of the history and political context of the drafting of the Kuwaiti Constitution, see, e.g., Nathan Brown, The Rule of Law in the Arab World: Courts in Egypt and the Gulf. Cambridge: Cambridge University Press, 2006: 129-186; Michael Herb, "The Origins of Kuwait's National Assembly." LSE Kuwait Programme Paper Series 39, 2016.

55 Ibid.

56 Constituent Assembly records are available in Arabic at http://www.kna.kw/clt-ht $\mathrm{ml}$ /run.asp?id=1568. 
its relationship with other guarantees of citizens' equality and rights in the Kuwaiti Constitution. Additional constitutional guidance with respect to sharia appears in Article 18, which states that matters of inheritance shall be governed by sharia and Article 9, which declares religion, morality, and love of the homeland as the founding pillars of the family. The Constitution does not specifically define Islamic sharia or its scope of application, thereby leaving it to the domain of the courts to interpret and apply this provision. The Constitution is also silent on the question of the supremacy of sharia over other constitutional principles or provisions.

The phrasing used in the Constitution of Kuwait, declaring sharia to be "a" rather than "the" primary source of legislation has proven to be of significance to the application of sharia in lawmaking. The Explanatory Memorandum of the Constitution indicates that Article 2 was designed to guide the legislature towards adopting an Islamic perspective without being prohibited from introducing provisions that stem from other sources, as dictated by public policy needs of the time. ${ }^{57}$ The Memorandum explains the rationale of not declaring sharia to be "the" main source of legislation in that this may conflict with practical needs that may require the state to adopt certain non-sharia based laws, especially in the areas of commerce, insurance, banking, loans, and criminal law. ${ }^{58}$ Expectedly, debates also emerged as to whether Article 2 could be understood to indicate that the Constitution permitted the promulgation of laws that are inconsistent or in contravention with sharia. The explanatory Memorandum does not completely resolve this issue, which later on would be settled by the Kuwaiti Constitutional Court. ${ }^{59}$ In practice today, sharia derived rules figure most prominently in the Kuwaiti Personal Status Laws, where both the sunni and shia versions of the law are based almost entirely on fiqh interpretations, in addition to Islamic banking regulations and some parts of the Penal Code.

Explanatory Memorandum to the Constitution of Kuwait (1962), art. 2.

58 Ibid.

59 Islamists in Kuwait have repeatedly expressed their dismay at what they consider a tenuous commitment to Islamic sharia in the country's constitution and by the liberal interpretation of the court of Article 2. Islamist blocs in parliament, mainly the Muslim Brotherhood and the Salafis, have repeatedly suggested that Islamic sharia should be made "the" primary source of legislation in the constitution. Major campaigns to amend the Constitution continue to be organized but have been unsuccessful to date. 
The Constitutional Court of Kuwait, established in $1973,{ }^{60}$ played the most significant role in setting the scope and guiding principles governing the application of sharia in the Kuwaiti legal system, and in particular, interpretation of Article 2 of the Constitution. It is now established in the jurisprudence of the Court that review of the constitutionality of legislation encompasses review for compatibility with Islamic sharia as well as interpreting the meaning of sharia under the Constitution and the law. This is of particular significance, and not without controversy, considering that the Kuwaiti Constitutional Court is composed of professional judges trained in law, rather than Islamic jurists or scholars. There is also nothing in Kuwaiti law that compels the Court to consult with an Islamic body or Islamic jurists in ruling over sharia-related constitutional controversies.

Kuwait's Constitutional Court has consistently held that Article 2 of the Constitution does not give rise to a duty to strike down laws simply because they may be deemed inconsistent with sharia, or its traditional interpretations. This bold standard was first established by the Court in 1992 in the context of a case that challenged the constitutionality of Articles 110 and 113 of the Kuwaiti Commercial Code, which permitted the charging of interest, widely considered as prohibited under sharia as a form or usury. ${ }^{61}$ The Court rejected the challenge and held that, since Article 2 of the Kuwaiti Constitution declared sharia to be "a source" and not "the only" source of legislation, it was permissible under the Constitution to incorporate other sources of legislation and adopt rules that may be inconsistent with traditional interpretations of sharia. ${ }^{62}$

This line of reasoning was then affirmed by the Court in multiple cases that followed. One of the most well-known cases was a 2009 challenge that disputed the election of two women, Rula Dashti and Aseel Al-Awadhi, to the National Assembly on the grounds that they were unveiled. The petitioner, who was a competing candidate, argued that by not wearing the veil (bijab), the two women had violated the 2005 amendment to National Assembly Election Law of 1962, which stipulated that the exercise by women of their political rights was subject to the accepted rules and conditions of Islamic sharia. ${ }^{63}$ The Court emphatically rejected the challenge and held that a law must be read narrowly in line with

60 Kuwaiti Constitutional Court Law (1973), as amended.

61 Kuwait Commercial Code (1980), arts. 110, 113.

62 Case 3/1992/Kuwait Constitutional Court, November 28, 1992.

63 The National Assembly Elections Law of 1962 was amended by Law 17 of 2005, giving women the rights to suffrage. Dashti and Al-Awadhi were the first two women elected to the Kuwaiti National Assembly in its history. 
the legislative will of the People's Assembly. Given that records of the legislative discussions did not include any reference to the meaning of sharia in the law, the Court declared that the term must be understood within the broader guidelines of the Kuwaiti Constitution, which "did not make Islamic sharia ... a lone source of legislation or prevent the legislator from incorporating other sources as public interest may necessitate." 64 The Court noted further that Article 2 must be understood within the context of broader constitutional guarantees of personal freedoms, freedom of conscience, and non-discrimination. ${ }^{65}$

To rule on questions of sharia interpretation outside of courts, Kuwait established a Directorate of Iftaa within the Ministry of Endowments and Islamic Affairs. ${ }^{66}$ This Directorate is responsible for issuing "official fatwas" - which generally follow the Maliki School of jurisprudence - and responds to questions related to Islam and sharia from other government institutions and from the general public. However, the influence of the Directorate of Iftaa on lawmaking remains limited, as the major Islamic currents within the country turn elsewhere for religious guidance. The Salafi movement, for example, which emerged as a strong actor in the Kuwaiti political scene starting in the early 1990s, typically turn to Salafi jurists in Saudi Arabia for fiqh answers, and the shia minority in Kuwait - representing about $20 \%$ of the population - largely turn to independent shia mujtahids in Iraq, Iran, Lebanon, and to a lesser extent, Bahrain. The Islamic Constitutional Movement, an offshoot of the Muslim Brotherhood, relies primarily on established Brotherhood ideological and religious sources for guidance. Furthermore, there is nothing in the Kuwaiti Constitution or law that obligates the government, legislature, or courts to consult the Directorate of Iftaa before passing legislation or adjudicating any matter.

The realm of personal affairs, or family law, remains the stronghold of sharia-based law in Kuwait, as in the vast majority of Arab states. Notwithstanding the secularization of almost all areas of law - save some criminal law (budood) provision that retain Islamic influences - personal status laws continue to be based exclusively on sharia and fiqh interpretations. ${ }^{67}$

64 Case 20/2008/Kuwaiti Constitutional Court, October 28, 2009.

65 Ibid.

66 This should not to be confused with the Directorate of Ifta'a and Tashri', primarily responsible for the drafting of legislation, http://site.islam.gov.kw/eftaa/Pages/a boutmanagement.aspx.

67 For a background on the historic evolution of Arab personal status laws and trajectories of reform and change, see Kristen Stilt, Salma Waheedi, et. al., "The 
The Kuwaiti Personal Status Law of 1984 governs all matters relating to personal status, including marriage, divorce, custody, and inheritance, and is applicable to the majority sunni Muslim population in Kuwait. The law is based primarily on majority interpretations of the Maliki school of fiqh but also incorporates a compilation of rules taken from all four sunni schools. ${ }^{68}$ In instances where the law does not sufficiently address a particular matter of personal status, the law instructs judges to rule in accordance with the Maliki rules and general principles. ${ }^{69}$ Article 346 of the Personal Status Law specifies that the law applies to sunni Muslims who follow the Maliki School, which represent the majority of Kuwait's sunni population, whereas adherents to other schools, which practically means Kuwait's shia minority, shall be governed by "their own rules." ${ }^{70}$ It was not until 2019 that a separate codified personal status law, Decree 24 of 2019, was issued to govern personal status matters of Kuwait's shia population. ${ }^{71}$

\subsection{Islamic sharia and the Judiciary}

There are no sharia courts in Kuwait. The Judiciary Law of 1990 organizes the court system and governs the jurisdiction of the different courts and all matters of judicial appointment, responsibilities, immunities, and dismissal. There are three levels of courts in Kuwait: courts of first instance (organized into minor courts, for small disputes, and major courts), courts of appeals, and a Cassation Court, in addition to the Constitutional Court which has exclusive jurisdiction over constitutional disputes and elections disputes. ${ }^{72}$ Within each of the three court levels, specialized chambers are created to adjudicate civil, criminal, commercial, administrative, and personal status matters, and courts may establish additional specialized chambers as needed. ${ }^{73}$

Ambitions of Muslim Family Law Reform." Harvard Journal of Law and Gender 41, 2018: 302-342.

68 Maliki, Hanbali, Hanafi, and Shafi'i.

69 Kuwait Personal Status Law (1984), art. 343.

70 Kuwait Personal Status Law (1984), art. 346; Article 346 also states that the law shall apply to cases of non-Muslims if different parties to a case adhere to different religions or sects.

71 Kuwait Jafari Personal Status Law (2019).

72 Kuwait Judiciary Law (1990), art.3; Constitutional Court Law (1973).

73 Kuwait Judiciary Law (1990), arts. 4, 6-8. 
The High Judicial Council and the Minister of Justice share the responsibility of appointing judges at all court levels in Kuwait. Article 20 of the Kuwaiti Judiciary Law (as amended in 1996), grants the Minister of Justice the primary responsibility for nominating new judges. New judges are generally nominated from amongst sitting public prosecutors and the High Judicial Council must then approve these nominations before an official appointment decision is issued by Emiri Decree. ${ }^{74}$ Promotion of sitting judges to senior judicial positions, such as the positions of President and Vice-President of the Cassation Court and Presidents of the High Court of Appeals and Courts of First Instance, are also issued by an Emiri Decree based on a proposal of the Minister of Justice and consent of the High Judicial Council. ${ }^{75}$ The Judiciary Law requires that a judge be a Muslim with a good reputation, but no special training in sharia is required beyond what is taught at the Faculty of Law in Kuwait. ${ }^{76}$ Graduates of either the Faculty of Law or Faculty of Sharia, or their equivalent, may serve as public prosecutors and judges. ${ }^{77}$

The family court chambers in Kuwait, which have jurisdiction over all personal status matters, from the first instance level to the highest appeals level, operate as units or chambers within each respective court level. In 2015, Kuwait enacted a law that established family court chambers in each governorate, responsible for the application of the Personal Status Law and adjudication of all disputes relating to family matters. ${ }^{78}$ After the 2019 promulgation of the Jafari Personal Status Law, separate Jafari and sunni family court chambers were created, each to apply its respective legislation. ${ }^{79}$ Non-Muslims can request that courts apply the customary or religious laws of their own communities. ${ }^{80}$ As in all other courts in Kuwait, judges of the family courts are not required to be Islamic jurists but may seek the expert advice of jurists or scholars trained in the relevant Islamic school of fiqh.

Up until recently, the judiciary in Kuwait has been exclusively the domain of male judges. In a historic move on July 5, 2020, the High Judicial Council approved a move by the Attorney General to promote eight wom-

74 Kuwait Judiciary Law (1990), art. 20.

75 Ibid.

76 Kuwaiti Judiciary Law (1990), art. 19.

77 Ibid.

78 Kuwait Family Courts Law (2015).

79 See Kuwaiti Ministry of Justice Services Portal, https://www.moj.gov.kw/AR/page s/DeptProcedure.aspx?ItemID=98.

80 Kuwait Personal Status Law (1984), art. 345A. 
en prosecutors to the position of judges. The eight new judges were among 22 Kuwaiti women appointed as prosecutors in $2014 .{ }^{81}$ This appointment came after a legal battle waged by Dalal Al-Hamdan, a Kuwaiti female applicant to the position of public prosecutor against the Ministry of Justice, which rejected her application with the justification that this position was reserved for men. ${ }^{82}$ The applicant, who had fulfilled all the prerequisites for the position, brought her case to the Administrative Circuit of the High Civil Court, ${ }^{83}$ arguing that the Ministry's practice was not justified by law - as the Judiciary Law does not exclude women from public prosecution or judicial appointments - and constituted gender-based discrimination in violation of the Constitution of Kuwait. ${ }^{84}$ The High Court ruled in favor of the petitioner in appeal, after having discussed in some detail the constitutional basis for the decision - including the language of Article 2 that limits the application of sharia as one amongst many sources of law - and an acknowledgment of the diverse views of sharia scholars with respect to the permissibility of the appointment of women to the judiciary. ${ }^{85}$ This was a groundbreaking decision at the time, and the promotion of these women to judicial positions became only a matter of time. Islamist lawmakers and conservative forces in Kuwait continue to express vehement opposition to the appointment of women to the judiciary, calling it "contrary to the nature of women," and in "opposition to sharia." 86

81 Habib Toumi, "Kuwaiti Women Poised to Become Judges." Gulf News, October 24, 2018, https:/gulfnews.com/world/gulf/kuwait/kuwaiti-women-poised-to-beco me-judges-1.2293191.

82 "Historic Ruling Paves the Way for Appointing Kuwaiti Women as Public Prosecutors." (Arabic) Al-Anba, April 23, 2012, https://www.alanba.com.kw/ar/kuwait-

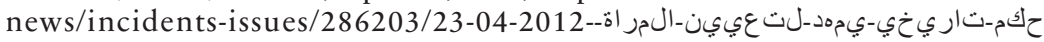

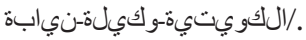

83 The claim had been previously rejected and then resubmitted for appeal. This court case was also not the first of its kind, as a previous case was brought by another female candidate to the position of public prosecutor and was rejected both in the first instance and in appeal.

84 Ibid.

85 Dalal Al-Hamdan v. Minister of Justice and Undersecretary of Justice, Administrative Case 3134 of 2011.

86 See Samir Salama, "Salafis Oppose Appointment of Women as Judges in Kuwait." Gulf News, July 3, 2020, https:/gulfnews.com/world/gulf/kuwait/salafis-oppose-a ppointment-of-women-as-judges-in-kuwait-1.72390852; Alma Hassoun, "Kuwait: Why the Delay in Appointing Women to the Judiciary?" (Arabic) BBC Arabic, July 2, 2020, https://www.bbc.com/arabic/middleeast-53257876. 


\subsection{Religious freedoms}

The Constitution of Kuwait of 1962 includes several provisions guaranteeing equality of citizens and non-discrimination on the basis of religion. Article 8 of the Constitution provides that the state shall guarantee security, tranquility and equal opportunity to all citizens, and Article 29(1) on Religion, Dignity, and Freedom establishes a right to non-discrimination on the basis of religion. ${ }^{87}$ It provides, in part, that all people are equal in human dignity and in public rights and duties before the law, regardless of their religion. ${ }^{88}$ Freedom of belief and religion is further emphasized in Article 35, which states that freedom of belief is unrestricted and that the state shall protect freedom in the observance of religious rites established by custom, provided such observance does not conflict with morals or disturb public order. ${ }^{89}$ It is important to note two possible grounds for restriction of religious freedoms here: first, the Explanatory Memorandum of the Constitution states that "religion" in the freedom of religion clause refers to Abrahamic religions, although it explains that nothing in the Constitution demands restricting the practice of other religions but rather leaves the matter to the discretion of the legislator. ${ }^{90}$ Second, conditioning religious practice upon "not disturbing the public order or morals" provides grounds for the legislator to enact laws that restrict the freedom of religious practice and worship using this very broad and undefined rationale. Finally, the Nationality Law of 1959 prohibits the naturalization of non-Muslims, even though there are natural-born Christian Kuwaiti citizens. ${ }^{91}$

The Penal Code of 1960 includes provisions that may be used to target free expression of religious beliefs, including prohibitions on contempt of any religion and expressing opinions that may offend, disrespect, or belittle any religion, its tenets, or rituals. ${ }^{92}$ The law does not prohibit proselytism, but proselytizing by non-Muslims may be prosecuted under Penal Code provisions that prohibit contempt of religion. In practice, freedom of religion in Kuwait is broadly guaranteed to both sunni and

87 Constitution of Kuwait (1962), arts. 8, 29(1).

88 Constitution of Kuwait (1962), art. 29(1).

89 Constitution of Kuwait (1962), art. 35.

90 Explanatory Memorandum to the Constitution of Kuwait (1962), art. 35.

91 Kuwait Nationality Law (1959), art. 4.

92 Kuwait Penal Code (1960), arts. 109-113. 
shia Muslims, who practice their rituals freely, ${ }^{93}$ although there have been cases when preachers have been sanctioned for engaging in political speech or sermons that were deemed to be in violation of the Penal Code's prohibitions of offensive speech. ${ }^{94}$ In past years, a number of activists and journalists were also convicted and sentenced for blasphemy and offensive speech. ${ }^{95}$

Christians in Kuwait are permitted to practice freely, within the general bounds of avoiding public disorder or offending Islam, and there are recognized Christian churches in Kuwait. Aside from Bahrain, Kuwait is the only other Arab Gulf monarchy with a citizen Christian population, estimated at 260 individuals. ${ }^{96}$ According to the US State Department's Religious Freedom Report, adherents of non-Abrahamic religions have generally reported that they are able to practice their religious rites in private spaces without government interference, as long as they do not disturb neighbors or violate public assembly regulations. There are no Hindu or Sikh temples, despite the presence of significant numbers of Hindu and Sikh expatriate workers in Kuwait. ${ }^{97}$

93 According to official statistics, out of an estimated total population of 4.42 million, $75 \%$ is Muslim, whereas the citizen population is about $99.9 \%$ Muslim (Population Statistical Report, Kuwait General Statistics Bureau (2019), https:// www.csb.gov.kw/Pages/Statistics? ID=67\&ParentCatID=1). It is estimated that Sunnis make up 70\% of Kuwait's Muslim population, while Shias account for about 30\% (Kuwait International Religious Freedom Report, US Department of State (2019), https://www.state.gov/wp-content/uploads/2020/06/KUWAIT-2019 -INTERNATIONAL-RELIGIOUS-FREEDOM-REPORT.pdf); the percentage of Shi'a includes Ismaili's and Ahmadis.

94 Kuwait International Religious Freedom Report, US Department of State (2019), https://www.state.gov/wp-content/uploads/2020/06/KUWAIT-2019-INTERNATI ONAL-RELIGIOUS-FREEDOM-REPORT.pdf.

95 See, e.g., Kuwait International Religious Freedom Report, US Department of State (2018), https:/www.state.gov/wp-content/uploads/2019/05/KUWAIT-2018-I NTERNATIONAL-RELIGIOUS-FREEDOM-REPORT.pdf.

96 Ismaeel Naar, "An Inside Look at the Native Christian Population of Kuwait." Al-Arabiya, December 25, 2017, https://english.alarabiya.net/en/features/2016/12/2 7/An-inside-look-at-a-Gulf-Christian-community.

97 Kuwait International Religious Freedom Report (2019), supra note 94. 
